\begin{tabular}{l} 
UADESIS \\
Universitas \\
Ahmad Dahlan \\
VOL. 3. No. 1, Januari 2022 \\
\hline
\end{tabular}

\title{
IDENTITAS TOKOH PRIBUMI DALAM CERPEN PENUNJUK JALAN KARYA IKSAKA BANU: KAJIAN PASCAKOLONIAL HOMI K. BHABHA
}

\author{
Risen Dhawuh Abdullah \\ Alumni Program Studi Sastra Indonesia, Fakultas Sastra, Budaya, dan Komunikasi, \\ Universitas Ahmad Dahlan, Jl. Ringroad Selatan, Tamanan, Bantul \\ risen1700025044@webmail.uad.ac.id
}

\section{Ilham Rabbani}

Magister Sastra, Fakultas Ilmu Budaya, Universitas Gadjah Mada, Jl. Sosio Humaniora, Bulaksumur, Yogyakarta ilhamrabbani@mail.ugm.ac.id

\section{Article history}

Received 30 November 2021

Revised 29 January 2022

Accepted 29 January 2022

Keywords

Identity

Iksaka Banu

Hybridity

Mimicry

Ambivalence

Postcolonial

Bhabha
This study aims to uncover an Indigenous character named Oentoeng in the short story "Penunjuk Jalan". The short story is one of Iksaka Banu's works contained in the book Semua untuk Hindia. The identity of the character that is trying to be dismantled includes hybridity, mimicry, and ambivalence. The theory used in this study is the postcolonial theory initiated by Homi K. Bhabha. The study used a qualitative descriptive method. There are three findings in this study. First, the identity of Oentoeng is a hybrid. Oentoeng absorbs Western values continuously, namely from his upbringing, education, and his association in the Dutch family environment. Second, mimicry as mockery by the character can be seen from three aspects, specifically the ability to speak Dutch possess Western medical knowledge, and to be able to devise a strategy of rebellion that made the VOC troubles as invaders. Third, Oentoeng's attitude of wanting to be angry and willing to provide assistance, treatment, and entertainment to the Dutch doctor and his porter who had an accident could be interpreted as a form of ambivalence in the Indigenous character.

This is an open access article under the CC-BY-SA license.

\section{Article history}

Received 30 November 2021

Revised 29 Januari 2022

Accepted 29 Januari 2022

Keywords

Identitas

Iksaka Banu

Hibriditas

Mimikri

Ambivalensi

Pascakolonial

Bhabha
Penelitian ini bermaksud membongkar identitas seorang tokoh Pribumi bernama Oentoeng dalam cerpen "Penunjuk Jalan". Cerpen tersebut merupakan salah satu karya Iksaka Banu yang termaktub dalam buku Semua untuk Hindia. Identitas tokoh yang berusaha dibongkar meliputi hibriditas, mimikri, dan ambivalensi. Teori yang digunakan ialah teori pascakolonial yang dikembangkan oleh Homi K. Bhabha. Metode yang dipilih adalah metode kualitatif-deskriptif. Adapun temuan dari penelitian ini: pertama, identitas tokoh Oentoeng berada pada posisi hibrid karena menyerap nilai-nilai Barat secara berkontinuitas, yakni dari asuhan, didikan, dan pergaulannya di lingkungan keluarga Belanda; kedua, mimicry as mockery yang dilakukan tokoh tersebut dapat dilihat berdasarkan tiga aspek, yakni kemampuan berbahasa Belanda, memiliki pengetahuan medis ala Barat, dan mampu merancang strategi pemberontakan yang membuat kerepotan VOC selaku penjajah; dan ketiga, sikap Oentoeng yang membenci penjajah namun sekaligus berkenan memberi pertolongan, pengobatan, dan perjamuan kepada dokter Belanda beserta portirnya yang mengalami kecelakaan, dapat dimaknai sebagai bentuk ambivalensi pada diri sang tokoh Pribumi. 


\section{PENDAHULUAN}

Kedatangan bangsa Eropa seperti Portugis, Spanyol, Inggris, dan Belanda ke Nusantara semenjak abad XVI, tidak pelak telah menimbulkan pertemuan dua kebudayaan besar: Timur dan Barat. Negara yang kini dikenal sebagai Indonesia pun, tanpa terkecuali, telah bersentuhan dengan keempat negara tersebut. Rempah-rempah menjadi daya magnet yang menarik keempatnya untuk datang. Dapat dikatakan bahwa pendudukan Malaka pada tahun $1511 \mathrm{M}$ oleh Portugis, di bawah komando Albuquerque, menandai dimulainya usaha pendirian kerajaan kolonial besar di Asia Tenggara oleh bangsa-bangsa Eropa tersebut (Stroomberg, 2018: 45).

Hampir seluruh wilayah kepulauan Nusantara dikuasai oleh keempatnya, dan Jawa, termasuk di dalamnya. Sebelumnya, Pulau Jawa pun telah terbagi-bagi berdasarkan daerah kekuasaan beberapa kerajaan besar. Dengan demikian, peradaban atau kebudayaan di pulau tersebut, dapat dikatakan telah mapan. Kedatangan bangsa Eropa, yang diwakili empat negara di atas, sebagai "pembawa" kebudayaan Barat, meniscayakan pertemuan kebudayaan dengan Timur yang diwakili oleh kerajaan-kerajaan di Jawa secara khusus. Dengan demikian, dimulailah "kelahiran" manusia-manusia hibrid di dalamnya.

Setelah suksesnya pendirian "kerajaan kolonial besar", atau yang secara sederhana dapat disebut sebagai fenomena penjajahan, dimulailah pula proses hegemoni kultural, yakni pengaruh dan penguasaan - yang tertanam dengan sangat dalam - para pihak Barat selaku penjajah atas pikiran, perasaan, sikap, dan perilaku masyarakat Pribumi sebagai pihak yangterjajah (Ratna dalam Turama, 2017). Kondisi tersebut dapat terus berlangsung, bahkan ketika sang penjajah telah melepaskan kekuasaannya atas wilayah geografis tersebut (Faruk, 2007: 16). Lebih jauh, efek yang tercipta ialah bersemayamnya inferioritas dalam diri masyarakat terjajah akibat hilangnya orisinalitas dan budaya lokal mereka (Loomba dalam Fajar, 2011).

Hal-hal demikian kemudian tercatat, dan menjadi dokumen sejarah. Peran para sejarawan dalam hal ini tidak dapat diabaikan. Akan tetapi, selain sejarawan, para pengarang juga tidak kurang berandil. Mereka menyajikan peristiwa-peristiwa sejarah dengan lebih "fleksibel" dibandingkan catatan para sejarawan yang terkesan kaku dan sarat data tersebut. Sudah jelas, bahwa fenomena yang terjadi, takkan lepas dari pengamatan para pengarang, sebab fenomena dalam masyarakat menjadi bahan penggarapan karya yang strategis.

Objek karya sastra adalah realitas-apa pun juga yang dimaksud dengan realitas oleh pengarang (Kuntowijoyo, 2006: 171). Secara mengerucut, sejarah juga merupakan realitas. Mengutip pendapat (Kuntowijoyo, 2006: 171), bahwa apabila realitas itu berupa peristiwa sejarah, maka karya sastra dapat: pertama, mencoba menerjemahkan peristiwa itu dalam bahasa imajiner dengan maksud untuk memahami peristiwa sejarah menurut kadar kemampuan pengarang; kedua, karya sastra dapat menjadi sarana bagi pengarangnya untuk menyampaikan pikiran, perasaan, dan tanggapan mengenai suatu peristiwa sejarah; dan ketiga, seperti juga karya sejarah, karya sastra dapat merupakan penciptaan kembali sebuah peristiwa sejarah sesuai dengan pengetahuan dan daya imajinasi pengarang. 


\begin{tabular}{l} 
MADESIS \\
Universitas \\
Ahmad Dahlan \\
VoL. 3o. 1, Januari 2022 \\
\hline
\end{tabular}

Pengarang yang mencatat peristiwa tersebut, dapat saja yang bersentuhan secara langsung dengan peristiwa kolonial, seperti misalnya Marah Roesli, Abdoel Moeis, Sutan Takdir Alisjahbana, dan lain-lain. Ada juga pengarang yang lahir dan bersentuhan hanya lewat catatan-catatan sejarah mengenai kolonialisme, seperti halnya Iksaka Banu. Nama Banu bukan lagi nama asing dalam kancah kesusastraan Indonesia mutakhir. Ia adalah penulis ternama di Indonesia, dengan sederet prestasi mentereng di bidang sastra. Sebut saja dua di antaranya: Pemenang Kusala Sastra Khatulistiwa edisi 2014 untuk kumpulan cerpen Semua untuk Hindia (2014) dan edisi 2019 untuk kumpulan cerpen Teh dan Pengkhianat (2019).

Kedua karya tersebut adalah bukti konsistensi Banu menggarap karya-karya bertema kolonialisme. Selain Semua untuk Hindia dan Teh dan Pengkhianat, satu lagi karyanya yang juga berlatar masa kolonial ialah novel Sang Raja (2017). Heryanto (2015) menyoroti sekaligus merangkum kecenderungan para pengulas karya Banu-khususnya Semua untuk Hindia-yang memandang fenomena perwatakan karakter dalam prosanya sebagai suatu keganjilan. Pandangan ganjil dari para pengamat tersebut, salah satunya mengisyaratkan adanya pikiran bahwa pihak penjajah atau Belanda tidak sepatutnya bersinggungan dengan sisi-sisi humanisme. Karya-karya Banu lahir untuk mematahkan hal tersebut. Ia memilih meletakkan tokoh-tokoh sentral ciptaannya, yang dominan merupakan tokoh berdarah Belanda, berada dalam lingkaran protagonis. Akan tetapi, salah satu cerpen yang termaktub dalam Semua untuk Hindia, justru memberikan porsi atau ruang hampir sama bagi eksplorasi tokoh dari Belanda dan Pribumi itu sendiri. Cerpen tersebut berjudul "Penunjuk Jalan" (2007), yang berkisah tentang kebaikan tokoh Pribumi bernama Oentoeng-lengkapnya adalah Untung Surapati-kepada seorang dokter dan portir yang mengalami kecelakaan dalam perjalanan.

Bagi peneliti, eksplorasi lebih terhadap tokoh Pribumi yang dilakukan Banu dalam karyanya merupakan hal yang menarik dan patut dikaji lebih jauh. Oleh sebab itu, dalam penelitian ini, cerpen "Penunjuk Jalan" dalam kumpulan cerpen Semua untuk Hindia tersebut akan coba dianalisis menggunakan teori pascakolonial yang dikembangkan oleh Homi K. Bhabha, guna berfokus melihat identitas tokoh Pribumi bernama Oentoeng yang diciptakan oleh Banu dalam karyanya.

Dalam cerpen "Penunjuk Jalan", tokoh Oentoeng dapat disebut sebagai tokoh sentral selain sang dokter Belanda (Jorijs Handlanger) yang sekaligus menjadi narator cerita (tokohAku). Alasan lain pemilihan tokoh Oentoeng adalah posisinya yang strategis: berada dalam semacam ketegangan antara latar belakang (berdarah Pribumi namun dididik Belanda) dan sosoknya sebagai penentang pihak Kompeni yang gigih saat itu. Dibandingkan tokoh lain dalam cerpen, Oentoeng juga merupakan tokoh yang paling kuat merepresentasikan hibriditas dan ambivalensi. Mimicry as mockery juga ia lakukan dalam cerpen tersebut. Oleh karena itu, pertanyaan yang kemudian berusaha dijawab oleh penelitian ini adalah, "Bagaimana bentuk hibriditas, mimikri, dan ambivalensi tokoh Oentoeng dalam cerpen 'Penunjuk Jalan' karya Iksaka Banu?" Sejalan dengan rumusan masalah tersebut, penelitian ini bertujuan untuk membongkar bentuk-bentuk hibriditas, mimikri, dan ambivalensi tokoh Oentoeng dalam cerpen terkait. 


\begin{tabular}{lc}
\hline MIMESIS & MIM \\
Universitas \\
Ahmad Dahlan
\end{tabular}

Beberapa penelitian terdahulu yang memiliki relevansi dengan penelitian ini, antara lain yang ditulis oleh Khuzaini (2018), Suweleh (2020), dan Fiaji, Fitrahayunitisna, dan Wulandari (2020). Pertama, dalam penelitiannya, Khuzaini (2018) berusaha mendeskripsikan kepribadian dan bentuk aktualisasi diri tokoh-tokoh utama dalam kumpulan cerpen Semua untuk Hindia. Teori yang digunakan ialah psikologi humanistik atau aktualisasi diri Abraham Maslow. Letak perbedaan antara penelitian Khuzaini dengan penelitian ini ialah objek formalnya. Khuzaini menggunakan perspektif psikologi sastra Maslow, sementara penelitian ini menggunakan perspektif pascakolonial Bhabha.

Kedua, penelitian Suweleh (2020) berfokus pada pengungkapan bentuk-bentuk keterbelahan tokoh-tokoh nativephilia dalam empat cerpen- "Selamat Tinggal Hindia", "Racun untuk Tuan", "Semua untuk Hindia", dan "Penunjuk Jalan"-yang termaktub di dalam antologi Semua untuk Hindia, menggunakan konsep split yang ditawarkan oleh Bhabha. Konsep tersebut mengindikasikan bahwa keterbelahan tidak hanya dialami oleh pihak terjajah, melainkan juga pihak penjajah. Terdapat kesamaan objek material dan perspektif pascakolonial yang digunakan oleh Suweleh dan peneliti, hanya saja perbedaannya terdapat pada konsep yang dieksplorasi. Suweleh mengeksplorasi konsep split, sementara penelitian ini berfokus pada hibriditas, mimikri, dan ambivalensi.

Terakhir, penelitian Fiaji, Fitrahayunitisna, dan Wulandari (2020) berupaya membahas nilai-nilai nasionalisme yang meliputi nasionalisme religius, nasionalisme kemanusiaan, nasionalisme berkerakyatan, dan nasionalisme berkeadilan dalam kumpulan cerpen Semua untuk Hindia menggunakan teori pascakolonial dengan menitikberatikan resistansi akan inferioritas kaum terjajah. Perbedaan antara penelitian tersebut dengan penelitian ini ialah perspektif pascakolonial yang digunakan: Fiaji, Fitrahayunitisna, dan Wulandari berfokus pada resistansi kaum terjajah, sementara peneliti berfokus pada identitas tokoh.

\section{METODE}

Metode yang digunakan adalah metode kualitatif-deskriptif. Moleong (2018: 6) menjelaskan bahwa penelitian kualitatif merupakan penelitian yang bermaksud memahami fenomena tentang hal yang dialami subjek penelitian secara holistik, dengan cara deskripsi dalam bentuk kata-kata dan bahasa, pada suatu konteks khusus yang alamiah dan dengan memanfaatkan berbagai metode ilmiah. Di dalam penelitian kualitatif, peneliti berposisi sebagai instrumen kunci.

Mengabstraksi pendapat Faruk (2017: 22-26), penelitian ini memiliki langkahlangkah sebagai berikut. Pertama, penentuan objek material dan objek formal. Objek material dalam penelitian ini adalah cerpen "Penunjuk Jalan" (2007) yang termuat dalam buku kumpulan cerpen Semua untuk Hindia (2014) karya Iksaka Banu, dan diterbitkan oleh Penerbit Kepustakaan Populer Gramedia (KPG). Sementara itu, objek formalnya ialah identitas tokoh yang meliputi hibriditas, mimikri, dan ambivalensi berdasarkan perspektif pascakolonial Bhabha. Kedua, pengumpulan data dilakukan dengan studi kepustakaan yang berfungsi menemukan data-data dalam cerpen "Penunjuk Jalan" sebagai sumber data atau 
data primer, serta teks-teks sekunder yang berkaitan dengan tokoh Pribumi bernama Oentoeng (Untung Surapati) dalam penelitian. Teknik yang dipergunakan adalah teknik simak-catat. Ketiga, analisis data dilakukan dengan teknik content analysis, yaitu peneliti melakukan pemaknaan terhadap data atau teks-teks yang telah diklasifikasikan dengan kerangka teori pascakolonial yang dikembangkan oleh Bhabha.

Bagian analisis data atau pembahasan akan dibagi ke dalam empat sub: 1) analisis hibriditas yang terjadi dalam diri tokoh Oentoeng serta ideologi tokoh-Aku (Jorijs) sebagai representasi dari ideologi penguasa (penjajah), yang selanjutnya memicu timbulnya mimikri dari tokoh Oentoneng - analisis ideologi sejatinya merupakan bagian dari analisis hibriditas, namun dispesifikkan dalam bab tersendiri guna memperjelas posisi dari masing-masing tokoh (Jorijs dan Oentoeng); 2) analisis mimicry as mockery yang dilakukan tokoh Oentoeng sebagai efek dari kondisi hibrid-nya, serta sebagai wujud resistansi yang dilakukan terhadap ideologi dan kebijakan-kebijakan pihak penjajah; dan 3) analisis kondisi ambivalen yang dialami oleh Oentoeng selaku tokoh Pribumi.

\section{PEMBAHASAN}

Seperti telah disinggung pada bagian Pendahuluan, penelitian ini menggunakan teori pascakolonial yang dikembangkan oleh Bhabha sebagai pisau analisisnya. Berikut ini merupakan hasil analisis terhadap cerpen "Penunjuk Jalan"-yang difokuskan pada tokoh Pribumi bernama Oentoeng-dengan menggunakan perspektif tersebut.

\section{Hibriditas Tokoh Oentoeng dan Pandangan Tokoh Jorijs sebagai Representasi dari Ideologi Penguasa}

Hibriditas merupakan konsep yang diperkenalkan oleh Bhabha dalam pemikiran pascakolonial yang ia kembangkan. Konsep lainnya yang juga ia perkenalkan dalam karyanya yang berjudul The Location of Culture adalah mimikri, dan ambivalensi. Menurut Setiawan (2018: 19), penggunaan istilah analogis tersebut merupakan cara Bhabha menggambarkan bangsa terjajah yang memanipulasi ketakberdayaan mereka menjadi kekuatan resistansi terhadap penjajah.

Hibriditas ialah istilah yang dipakai untuk mengacu pada interaksi antara bentukbentuk budaya yang berbeda, yang dapat menghasilkan pembentukan budaya dan identitas baru dengan sejarah dan perwujudan tekstual sendiri (Day dan Foulcher, 2008: 12). Akan tetapi, dalam kajian pascakolonial, hibriditas mengacu pada pertukaran silang budaya. Hibriditas tidak hanya mengarahkan perhatian pada produk-produk paduan budaya itu sendiri, tetapi lebih kepada cara produk-produk budaya tersebut dan penempatannya dalam ruang sosial dan historis di bawah kolonialisme, menjadi bagian dari pemaksaan penolakan hubungan kekuasaan kolonial (Day dan Foulcher, 2008: 13).

Tokoh Oentoeng sebagai orang berdarah Pribumi, selain karena pertemuan dua kebudayaan besar (Barat dan Timur) secara meluas karena kolonialisme di Nusantara, juga mengalami penyerapan nilai-nilai Barat secara khusus lewat tokoh bernama Cnoll dan Moor. Oentoeng pernah tinggal dan dididik di lingkungan keluarga Belanda, tepatnya dalam 
lingkungan Keluarga Cnoll (yang kemudian beralih ke Edeleer Moor), kendati tidak dijelaskannya secara eksplisit dan panjang lebar kepada tokoh-Aku saat pertemuan pertama mereka dalam cerpen. Pertemuan kedua tokoh terjadi dalam perjalanan, ketika sang dokter Belanda mengalami kecelakaan dan membutuhkan pertolongan medis bagi dirinya dan sang portir:

"Aku pernah tinggal bersama keluarga Belanda yang kerap berurusan dengan chirurgijnen. Aku tahu benar pekerjaanmu, Tuan Dokter," ujarnya dalam bahasa Belanda. Ya, Belanda! (hlm. 120)

...

“Tuan!” Sang Pangeran menggeleng. "Kuhabiskan masa kecilku di Batavia. Aku melihat semuanya. Kurasa penduduk di sana pun melihat, bahwa sejak direbut Kompeni enam puluh tahun silam, kota itu menjelma menjadi kota terkutuk. ..." (Banu, 2014: 123)

Hibriditas tokoh Oentong yang diperoleh dari pergaulannya dalam lingkungan keluarga Belanda, dalam cerpen "Penunjuk Jalan" diungkapkan lagi menjelang ending cerita, yakni ketika sang dokter memperhatikan sebuah lukisan karya Jacob Jansz Coeman (seorang pelukis ternama Hindia) yang terpampang di dinding ruangan Asisten Sekretaris Dewan Hindia bernama Vuijborn. Keberadaan sosok Oentoeng atau Pangeran (panggilan lainnya dalam cerpen) dalam lukisan membuat tokoh-Aku terheran. Vuijborn menjelaskan kepada tokoh dokter Belanda perihal lukisan tersebut:

"Perkenalkan: Keluarga Cnoll, dilukis oleh Jacob Jansz Coeman, pelukis termahal Hindia," Vuijborn memegang bingkai lukisan. "Yang bergaun hitam itu Cornelia."

Kuamati lebih dekat. Mendadak aku tersentak. Di sana, di belakang Cornelia. Dilukis dalam nuansa hijau kecokelatan. Seorang pemuda berambut panjang memanggul payung militer di bahu kanan, sementara tangan kirinya dengan jenaka mengutil jeruk yang dibawa seorang budak wanita.

"Mijn God! Tak salah! Aku nyaris histeris. Sang Pangeran.” (Banu, 2014: 127-28)

Relasi antaranggota keluarga, kendati hanya terjadi dalam konteks pemungutan dari yang menjajah kepada yang terjajah, tetap dapat dipandang sebagai hubungan fundamental tempat terjadinya transfer nilai-nilai kehidupan. Dibesarkan dalam keluarga Belanda, membuat identitas Oentoeng berada pada posisi hibrid karena menyerap nilai-nilai Barat secara berkontinuitas.

Pernyataan sang tokoh bahwa dirinya menghabiskan masa kecil di Batavia dan "pernah melihat semuanya", mengindikasikan bahwa dirinya menyerap berbagai hal, mulai dari pandangan, tata krama, gaya hidup, dan hal-hal lain yang bernuansa Eropa. Situasi yang dialami Oentoeng, setidaknya dapat dijadikan sebagai contoh kasus dari pernyataan Young (2003: 79), bahwa hibriditas melibatkan proses interaksi yang menciptakan ruang sosial baru, di mana makna baru diberikan, serta memungkinkan artikulasi pengalaman perubahan dalam masyarakat yang terpecah oleh modernitas, dan mereka memfasilitasi tuntutan konsekuensi untuk transformasi sosial. Dengan demikian, menjadi hal yang wajar apabila sang tokoh berdarah Pribumi digambarkan memiliki wawasan luas dalam cerpen "Penunjuk Jalan". 
Berkaitan dengan kondisi tokoh Oentoeng yang menyerap berbagai hal, mulai dari pandangan, tata krama, gaya hidup, dan hal-hal lain yang bernuansa Eropa tersebut, dapat dikatakan bahwa sejatinya ia telah mengalami proses hegemoni oleh ideologi penguasa atau penjajah (pihak Belanda) pada masa-masa tersebut. ${ }^{1}$ Keadaan itu pun terus bertahan dalam dirinya sampai masa ketika terjadinya pertemuan dengan sang tokoh-Aku. Untuk melihat bagaimana ideologi pihak penguasa bekerja sekaligus ditentang oleh tokoh Oentoeng (dalam pembahasan mimikri), dapat dilakukan dengan mencermati cara pandang tokoh Jorijs selaku orang Belanda totok dalam cerpen, baik lewat tuturan-tuturan (dialog) antartokoh maupun monolog tokoh-Aku selaku narator utama. Cara pandang dan sikap tersebut, kemudian dicermati kembali pada bagian pembahasan mimicry as mockery, untuk membuktikan bahwa memang terdapat ideologi penguasa, baik yang ditentang maupun bertahan dalam diri tokoh terjajah (Oentoeng).

Pertama, tokoh-Aku atau Jorijs sendiri adalah seorang Belanda totok yang diutus oleh pemerintah Belanda di Eropa untuk membantu mengatasi permasalahan yang sedang menimpa Batavia, yang artinya ia berada di pihak yang pro atau mendukung penjajahan mereka atas tanah Hindia Belanda. Posisi pro tersebut ia jelaskan secara gamblang di hadapan tokoh Oentoeng ketika mereka bercaka-cakap:

Aku baru tiba dari Rotterdam minggu lalu. Dan karena Bandar Sunda Kelapa sedang diperbaiki, kapalku harus merapat di Banten. Perlu tiga hari perjalanan kereta pos untuk ke Batavia. Lusa aku harus menghadap Gubernur Jenderal Speelman, membicarakan jabatan baruku sebagai Ketua Dewan Kesehatan Batavia. (Banu, 2014: 118-119)

Lebih jauh, ia juga menjelaskan bahwa ia diminta langsung oleh Pimpinan Kompeni untuk meneruskan pekerjaaan dokter resmi pertama di Batavia bernama Jacobus Bontius, sebab saat itu Batavia sedang didera penyakit perut dan beri-beri parah, sementara mutu para chirurginjen mereka semakin merosot, dan pendahulu-pendahulu mereka yang lebih terampil bahkan turut menjadi korban penyakit-penyakit tersebut (Banu, 2014: 122-123).

Ideologi tokoh Oentoeng secara nyata berseberangan dengan yang dilakukan oleh tokoh-Aku tersebut. Ia menegaskan dan melontarkan pernyataan kepada lawan bicaranya, bahwa cara hidup orang-orang Belanda yang sama seperti tokoh-Aku, tidak hanya menimbulkan kerusakan lingkungan dari segi fisik, melainkan juga dari aspek budaya berupa hegemoni perebutan kekuasaan, gaya hidup tidak sehat, dan sebagainya yang melanda Kerajaan Mataram (Banu, 2014: 123). Sederhananya, ia menyayangkan keadaan tersebut.

\footnotetext{
${ }^{1}$ Definisi ideologi yang dirujuk dalam konteks ini ialah kumpulan konsep bersistem yang dijadikan asas pendapat (kejadian), yang memberikan arah dan tujuan untuk kelangsungan hidup, atau secara sederhana merupakan cara pandang dan berpikir seseorang atau suatu golongan tertentu (KBBI Daring, 2021). Cabanis, de Tracy, dkk. (dalam Althusser, 2007: 185-186) menyebut ideologi sebagai sistem ide-ide dan gambarangambaran yang mendominasi pikiran seseorang atau sebuah kelompok sosial. Menurut Althusser (2007: 167168), ideologi sendiri didistribusikan lewat institusi-institusi seperti institusi keagamaan, pendidikan, keluarga, hukum, politik, serikat buruh, komunikasi (pers, radio, televisi, dll.), dan kebudayaan (kesusastraan, seni, olahraga, dll.). Baginya, manusia tidak perlu dibebaskan dari ideologi, sebab memiliki sisi baik, yakni sebagai reaksi terhadap suatu dominasi - setiap penindasan akan menghasilkan usaha-usaha pada pihak tertindas untuk melepaskan diri.
} 


\begin{tabular}{lc}
\hline MIMESIS & MIM \\
Universitas \\
Ahmad Dahlan & VoL. 3. No. 1, Januari 2022 \\
\hline
\end{tabular}

Kedua, sebagai orang Eropa yang dalam konteks penjajahan selalu diposisikan sebagai yang superior, beradab, cerdas atau berpengetahuan luas, dan sebagainya — sementara pihak terjajah atau pribumi menjadi oposisi binernya - maka tidak mengherankan ketika di dalam narasi cerpen, ditemukan cara pandang dari tokoh-Aku yang skeptis, bahkan mengarah ke sinis, terhadap ketulusan pertolongan yang mereka terima dan pengetahuan dari kelompok Oentoeng sendiri:

Aku mulai cemas. Seorang kawan pernah berkisah tentang gerombolan penyamun yang banyak berkeliaran di di hutan Jawa. Mereka gemar merampok dan membantai saudagar Belanda atau Tionghoa yang kebetulan memintas hutan.

$\cdots$

Jantungku berdebar. Inikah gerombolan penyamun itu? Belasan penunggang kuda di belakang kedua orang itu memang cukup mewakili gambaran umum penyamun: Berkumis tebal, berkulit legam, serta menyimpan kelewang panjang di punggung. (Banu, 2014: 119)

"Aku pernah tinggal bersama keluarga Belanda yang kerap beruruasan dengan chirurgijen. Aku tahu benar pekerjaanmu, Tuan Dokter," ujarnya dalam bahasa Belanda. Ya, Belanda!

"Donder er bliksem!" aku melompat mundur. "Betapa fasih. Pujianku untuk Tuan," lanjutku. Kali ini sepenuhnya dalam bahasa Belanda. (Banu, 2014: 120)

Pangeran melempar senyum. Kutangkap kembali sorot ganjil lewat tarikan bibir dan matanya, seperti saat pertama melihatku tadi. Berhati-hatilah dengan bumiputra, kepala mereka penuh muslihat. Terngiang lagi nasihat temanku. Tapi adakah tawaran yang lebih baik? ... Adakah penyamun fasih berbahasa Belanda? (Banu, 2014: 122)

Kutipan tersebut menunjukkan cara pandang dan berpikir yang khas Orientalisme: mereka melakukan penilaian budaya serta sejarah bangsa Timur secara otoritatif. Orientalisme menjadi perspektif pada pengetahuan Barat tentang dunia timur, yang menggambarkan timur sebagai sesuatu yang secara negatif kontras dengan Barat (putih-hitam, kuat-lemah, beradabbarbar, pintar-bodoh, dan oposisi biner lainnya), yang notabene keseluruhan dan kecenderungannya selalu mengarah kepada fungsi untuk merendahkan masyarakat Timur (Setiawan, 2018: 39).

Kentara dalam konteks cerpen tersebut, bahwa di satu sisi tokoh-Aku mengidentifikasi dirinya selaku subjek dari Barat yang berpengetahuan dan beradab (dari segi pilihan dan cara berbahasa, berpenampilan, bersikap, dsb.), sementara di sisi seberangnya tokoh Oentong dan kelompoknya adalah penyamun barbar yang perlu diwaspadai. Singkatnya, ada tindakan menggeneralisasi: seluruh orang Timur adalah mereka yang tidak memahami bahasa masyarakat kelas atas di Hindia Belanda (bahasa Belanda), serta patut diwaspadai karena di kepala mereka tersimpan berbagai muslihat yang dapat mengancam subjek-subjek lain yang mereka temui, tidak terkecuali pihak Barat yang memang beroposisi dengan mereka.

Ketiga, dari aspek medis, tokoh-Aku sebagai seorang dokter dari Eropa secara jelas digambarkan sebagai penganut paham positivistik-empiris. Cara, proses, dan jenis obat yang dibutuhkan dalam tindkan medis harus berdasarkan data-data empiris sebagaimana lazimnya sains dalam pandangan mereka selaku orang-orang Barat. Oleh sebab itulah, ia digambarkan 
tertantang, bahkan sempat memprotes tindakan medis yang dilakukan Kyai Ebun terhadap tokoh Joep sebagaimana kutipan berikut.

Dalam bilik, kusaksikan Joep mengelepar seperti ayam disembelih. ...

"Apa yang Tuan lakukan? Ia bisa lumpuh, kurenggut tangan si tabib seraya memaki dalam bahasa Melayu. Kutumpahkan pula amarahku kepada Pangeran. Ia diam, tapi mendadak jarinya mamatuk bahuku, membuat lenganku gontai.

"Tuan harus percaya kepada Kyai Ebun," kata Pangeran. "Telah ratusan kali ia melakukan pengobatan semacam ini. Memang sakit. Tapi lihat hasilnya."

"Orang Belanda mengobati sakit dari luar. Kami membiarkan tubuh menyembuhkannya dari dalam," Pangeran berdiri di belakangku dengan dua gelas the panas. Diangsurkannya segelas. ... (Banu, 2014: 124-25)

\section{Mimicry as Mockery dalam Bahasa, Pengetahuan Medis, dan Strategi Perang}

Hibriditas subjek memicu timbulnya mimikri. Dijelaskan oleh Bhabha (dalam Foulcher 2008: 105), bahwa mimikri merupakan reproduksi belang-belang subjektivitas Eropa di lingkungan kolonial yang sudah tidak murni, yang tergeser dari asal-usulnya, dan terkonfigurasi ulang dalam cahaya sensibilitas dan kegelisahan khusus kolonialisme. Sebenarnya, mimikri lebih mendekati olok-olok, dalam artian berupa resistansi dengan peniruan yang memunculkan kesan olok-olok.

Peniruan yang dilakukan pihak terjajah, dalam hal ini tidak pernah mencapai titik final atau purna. Dengan kata lain, peniruan mereka merupakan hal buruk, terlebih jika dikaitkan sebagai alat resistansi. Kita kemudian mengenal istilah "mimicry as mockery". Tentang hal ini, (Bhabha, 1994: 123) mengungkapkan bahwa, "The effect of mimicry on the authority of colonial discourse is profound and disturbing. For in 'normalizing' the colonial state or subject, the dream of post-Enlightenment civility alienates its own language of liberty and produces another knowledge of its norms," dan ia lanjutkan pada bagian berikutnya, "it is from this area between mimicry and mockery, where the reforming, civilizing mission is threatened by the displacing gaze of its disciplinary double, that my instances of colonial imitation come."

Setidaknya, mimikri atau peniruan yang dilakukan oleh tokoh Oentoeng terhadap pihak penjajah, dapat dilihat berdasarkan tiga aspek: berbahasa, pengetahuan medis, dan strategi perang. Pertama, tokoh Oentoeng digambarkan sebagai tokoh Pribumi yang fasih berbicara dalam bahasa Belanda. Adegan tersebut digambarkan pada pertemuan pertama antara sang dokter dengan Oentoeng juga. Oentoeng kemudian memperkenalkan dirinya, dan menjelaskan bahwa dirinya pernah hidup di bawah asuhan orang Belanda (sebagaimana dijelaskan dalam pembahasan hibriditas):

"Aku pernah tinggal bersama keluarga Belanda yang kerap berurusan dengan chirurgijnen. Aku tahu benar pekerjaanmu, Tuan Dokter," ujarnya dalam bahasa Belanda. Ya, Belanda! "Donder en bliksem!" aku melompat mundur. "Betapa fasih. Pujianku untuk Tuan," lanjutku. Kali ini sepenuhnya dalam bahasa Belanda.

Ya, aku akan selamat. Adakah penyamun fasih berbahasa Belanda? (Banu, 2014: 120) 
Kedua, meskipun tidak dijelaskan secara tersurat dalam cerpen "Penunjuk Jalan", penggambaran tokoh Oentoeng yang memiliki pengetahuan mengenai dunia medis ala Barat justru dihadirkan berupa paparan mengenai sebab kecarut-marutan masalah kesehatan di Hindia, khususnya Batavia, serta sangkalan terhadap protes sang dokter Belanda ketika melihat seorang tabib rombongan Oentoeng beraksi. Artinya, dalam hal ini mimicry sang tokoh Pribumi terhadap pandangan orang Belanda bergerak ke arah mockery, yakni keberanian menjelaskan secara objektif penyebab kecarut-marutan dan sangkalan mengenai proses pengobatan ala orang-orang Eropa. Berikut merupakan kutipan pernyataan pandangan tokoh Oentoeng:

"Kuhabiskan masa kecilku di Batavia. Aku melihat semuanya. Kurasa penduduk di sana pun melihat, bahwa sejak direbut Kompeni enam puluh tahun silam, kota itu menjelma menjadi kota terkutuk. Sungai Ciliwung dicabik menjadi puluhan kanal sehingga arusnya melemah. Lumpur mengendap di sana-sini, menciptakan dinding-dinding parit yang becek. Kalau sedang pasang, seisi laut menerjang kota. Saat surut, bangkai ikan serta kotoran manusia terperangkap di selokan dan parit-parit tadi. Menebarkan udara tak sehat.” (Banu, 2014: 123)

Ia berusaha melihat dan memaparkan secara objektif semua penyebab terjadinya kekacauan dan masalah kesehatan yang melanda Batavia saat itu, yang notabene berusaha diatasi si tokoh-Aku. Dengan pengetahuan tersebut pula, ia menyerang secara lisan pihak Belanda (yang diwakili si tokoh-Aku) yang ia anggap sebagai biang keladi dari berbagai permasalahan Batavia. Seperti diketahui, pemandangan itu diperoleh Oentoeng ketika masih berada di bawah asuhan orang Belanda. Pemandangan yang dianggap lazim oleh pihak Belanda karena alasan proyek kolonial tersebut, pada mulanya dianggap lazim juga oleh Oentoeng selaku sosok Pribumi. Akan tetapi, karena tumbuhnya kesadaran, pandangannya tersebut pun bergeser terhadap pembelaan Pribumi dan kondisi alam mereka yang dirusak oleh pihak penjajah.

Dalam konteks pengobatan medis, sangkalan dalam kutipan berikut juga dapat dimaknai sebagai mockery tokoh Oentoeng kepada sang dokter Belanda beserta pandangan medis orang-orang Eropa:

... Seorang lelaki tua sigap mengompres dahinya dengan dedaunan yang ditumbuk halus. Agaknya ia seorang tabib. Aku sungguh merasa tertantang. Namun ajakan pangeran untuk berkumpul di bilik depan mengurungkan niatku meyaksikan si tabib beraksi.

Dalam bilik, kusaksikan Joep mengelepar seperti ayam disembelih. ...

"Apa yang Tuan lakukan? Ia bisa lumpuh, kurenggut tangan si tabib seraya memaki dalam bahasa Melayu. Kutumpahkan pula amarahku kepada Pangeran. Ia diam, tapi mendadak jarinya mamatuk bahuku, membuat lenganku gontai.

‥

"Orang Belanda mengobati sakit dari luar. Kami membiarkan tubuh menyembuhkannya dari dalam," Pangeran berdiri di belakangku dengan dua gelas the panas. Diangsurkannya segelas. ... (Banu, 2014: 124-25) 


\begin{tabular}{l} 
MIMESIS \\
Universitas \\
Ahmad Dahlan \\
VoL. 3o. 1, Januari 2022 \\
\hline
\end{tabular}

Sangkalan tersebut membuktikan adanya pemahaman metode pengobatan yang digunakan oleh orang-orang Barat, yang notabene dianggap tidak lebih efektif dari cara orang-orang Timur (Pribumi) "merangsang" kinerja tubuh dalam memperbaiki dirinya sendiri. Pemahaman mengenai dunia medis ala Barat oleh Oentoeng, dapat dimaknai sebagai kondisi bahwa sebelumnya ia pun pernah mengamini keefektifan metode tersebut - ia sempat menjadi "penganut" cara pandang positivistik-empiris dari segi medis sebagaimana tokoh Jorijs. Hal itu menandakan bahwa Oentoeng juga melakukan mimikri dalam konteks dunia medis. Akan tetapi, sekali lagi, sangkalannya kemudian dapat dimaknai pula sebagai mockery karena penemuan metode ala Timur yang kini ia anggap lebih alami dan efektif dalam memperbaiki tubuh manusia.

Ketiga, telah disinggung sebelumnya dalam pembahasan tentang hibriditas tokoh Oentoeng, bahwa sang dokter atau tokoh-Aku melihat sosok Oentoeng dengan posisi memegang payung militer dalam lukisan karya Coeman. Artinya, dapat diasumsikan bahwa identitasnya sebagai oposisi atau penentang orang-orang Belanda yang menjajah kaum Pribumi-sebagaimana dinarasikan dalam cerpen-bermula dari pemahamannya terkait kemiliteran Belanda. Tokoh Oentoeng, sebagaimana disinggung pada halaman ke-128 buku Semua untuk Hindia, dikenal sebagai sosok yang kejam dan tidak mengenal ampun ketika berhadapan dengan Kompeni: Vuijborn menyorongkan wajahnya mendekati kanvas. "Kalau benar, ajaib sekali kau bisa
lolos," gumamnya. "Ia pemimpin penyamun. Pembenci Belanda. Membunuh banyak tentara
sejak lolos dari Stadhuis. Buronan Kompeni nomor satu. Minggat dari rumah Cnoll karena tak
boleh lagi menjadi pemegang payuung oleh anak lelaki Pieter. Konon ia lalu dipelihara oleh
Edeleer Moor, dan membuat skandal cinta dengan Suzanna, anak gadis Moor." (Banu, 2014:
128)

Dalam hal ini, perlu kiranya merujuk kepada fakta sejarah — sebab setelah titimangsa cerpen, pengarang membubuhkan keterangan bahwa cerpen "Penunjuk Jalan" terinspirasi dari roman Surapati (1950) karya Abdoel Moeis dan cerita perjalanan Untung Surapati, seorang pahlawan Indonesia - bahwa Oentoeng memang dikenal sebagai sosok Pribumi yang gigih menentang penjajahan Belanda di Tanah Nusantara. Dapat dikatakan bahwa mockerynya dalam hal ini berkaitan dengan perlawanan secara langsung atau perlawanan fisik terhadap Belanda, berbekal pemahaman mumpuni mengenai strategi militer Belanda yang pernah ia peroleh dari didikan Vereenigde Oostindische Compagnie (VOC) sebelumnya (Raditya, 2018). Oleh sebab itulah, Oentoeng atau Untung Surapati dalam sejarah Nusantara dikenal sebagai sosok yang sukses membuat pihak Belanda kerepotan karena ulah dan dan tindakan memberontaknya terhadap VOC atau Kompeni (Wijaya, dkk., 2019).

\section{Jejak Ambivalensi dalam cerpen Penunjuk Jalan: Memusuhi Sekaligus Menolong Penjajah}

Telah diungkapkan pada bagian pembahasan mimikri, lewat kutipan dari Bhabha, bahwa mimikri sendiri disebabkan adanya hubungan yang ambivalen antara pihak penjajah dan pihak yang terjajah. Sikap ambivalensi ini dipicu oleh adanya kecintaan terhadap suatu 
hal sekaligus membencinya. Menurut Bhabha (dalam Loomba, 2016: 229-30) ambivalensi tidak hanya dapat dibaca sebagai petanda trauma subjek kolonial, melainkan juga sebagai ciri cara kerja otoritas kolonial serta dinamika perlawanan. Bhabha juga mengungkapkan bahwa kehadiran kolonial itu selalu ambivalen, terpecah antara menampilkan dirinya sebagai asli dan otoritatif dengan artikulasinya yang menunjukkan pengulangan dan perbedaan. Dengan kata lain, identitas kolonial itu tidak stabil, meragukan, dan selalu terpecah.

Dalam cerpen "Penunjuk Jalan", tokoh Oentoeng digambarkan memiliki kecenderungan ambivalensi, yakni memusuhi pihak penjajah, namun sekaligus berkenan menolong sang dokter Belanda beserta portirnya yang mengalami kecelakaan. Tindakan membantu tersebut memang didasari oleh situasi darurat, namun tetap dapat dimaknai sebagai ambivalensi karena Pribumi yang membenci pihak penjajah semestinya melakukan penumpasan terhadap musuhnya. Perilaku baik Oentoeng terhadap tokoh-Aku dalam cerpen, digambarkan sebagai berikut.

“... Keretaku masuk jurang. Portir ini butuh bantuan kesehatan. Kami akan sangat berterima kasih bila Tuan bersedia menunjukkan jalan ke Batavia."

Si pemuda melepaskan tatapannya. Ketegangan mencair. (Banu, 2014: 120)

Tidak hanya penerimaan yang baik, tokoh Oentoeng bahkan berkenan membantu sang dokter Belanda dan memberi perawatan pada portirnya yang mengalami luka parah. Ia pun berkenan menunjukkan rute terdekat untuk sampai ke Batavia:

“... Sebaiknya Tuan ikut kami. Biarkan portir itu mendapat perawatan. Besok pagi kami tunjukkan jalan tersingkat ke Batavia."

"Betapa budiman," aku membungkuk. "Joep dan aku akan selalu mengingat kebaikan Tuan."

Pangeran melempar senyum. ... (Banu, 2014: 122)

Disebabkan kebaikan perlakuan, berkali-kali tokoh-Aku memeri pujian pada perlakuan Oentoeng terhadap "orang luar" yang membutuhkan pertolongan, padahal notabene yang ia tolong adalah bagian dari orang Belanda dan yang sekaligus akan ditugaskan menjalankan proyek kolonial. Ia menunjukkan ambivalensi sikap terhadap orang Belanda yang seharusnya ia musuhi. Ambivalensi sikap tokoh pribumi ini seperti didasari rasa kemanusiaan:

“... Nah, di balik sana kami tinggal. Tak banyak orang luar yang bisa masuk dengan mudah. Tapi kami juga tidak bisa membiarkan teman Tuan seperti itu bukan?”

Kutoleh Joep. Masih terbaring layu.

"Pangeran sungguh berhati mulia," aku mengangguk, lalu bergegas mengejar kudanya yang dipacu kencang. (Banu, 2014: 124)

Perlakuan baik Oentoeng dan rombongannya terhadap pihak musuh (Belanda) tidak hanya berhenti pada pertolongan medis, melainkan suguhan makanan dan minuman juga, bahkan sang tokoh Pribumi memilih porsi yang lebih sedikit dibandingkan sang dokter Belanda. Hal itu dijelaskan dalam kutipan pernyataan narator cerita: 
Syukurlah sebentar kemudian disuguhkan kopi, air, dan makan malam. Aku menyantap semuanya dengan lahap, namun segera berhenti demi menyaksikan kecilnya porsi yang diambil Pangeran dan pengikutnya. (Banu 2014: 125)

Dengan demikian, secara singkat dapat dikatakan bahwa ambivalensi tokoh Oentoeng dalam cerpen "Penunjuk Jalan" ialah berupa penerimaan, pemberian pertolongan, dan perlakuan baik terhadap seorang dokter Belanda, yang notabene merupakan bagian dari pihak Belanda yang sejatinya ia musuhi.

\section{KESIMPULAN}

Berdasarkan analisis terhadap cerpen "Penunjuk Jalan" karya Iksaka Banu menggunakan perspektif pascakolonial Homi K. Bhabha, dapat ditarik kesimpulan sebagai berikut. Pertama, karena dibesarkan dalam asuhan, didikan, dan pergaulan dengan keluarga Belanda, membuat identitas tokoh berdarah Pribumi bernama Oentoeng berada pada posisi hibrid karena menyerap nilai-nilai Barat secara berkontinuitas. Kedua, mimicry as mockery yang dilakukan tokoh tersebut dapat dilihat berdasarkan tiga aspek, yakni kemampuan berbahasa Belanda, memiliki pengetahuan medis ala Barat, dan mampu merancang strategi pemberontakan yang membuat kerepotan VOC selaku penjajah. Terakhir, sikap Oentoeng yang membenci penjajah namun sekaligus berkenan memberi pertolongan, pengobatan, dan perjamuan kepada dokter Belanda beserta portirnya yang mengalami kecelakaan, dapat dimaknai sebagai bentuk ambivalensi sang tokoh yang dapat ditemui dalam cerpen "Penunjuk Jalan".

\section{DAFTAR PUSTAKA}

Althusser, Louis. 2007. Filsafat sebagai Senjata Revolusi. Yogyakarta: Resist Book.

Banu, Iksaka. 2014. Semua untuk Hindia. Jakarta: Kepustakaan Populer Gramedia.

Bhabha, Homi K. 1994. The Location of Culture. New York: Routledge Classics.

Day, Tony, and Keith Foulcher. 2008. "Bahasan Kolonial dalam Sastra Indonesia Modern: Catatan Pendahuluan." P. 468 in Sastra Indonesia Modern Kritik Postkolonial. Jakarta: Yayasan Obor Indonesia.

Fajar, Yusri. 2011. "Negosiasi Identitas Pribumi dan Belanda Dalam Sastra Poskolonial Indonesia Kontemporer." Literasi 1(2):178-86.

Faruk. 2007. Belenggu Pascakolonial: Hegemoni \& Resistensi dalam Sastra Indonesia. Yogyakarta: Pustaka Pelajar.

Faruk. 2017. Metode Penelitian Sastra: Sebuah Penjelajahan Awal. Yogyakarta: Pustaka Pelajar. 
Fiaji, Noveria Anggraeni, Fitrahayunitisna, dan Prisca Kiki Wulandari. 2020. "Potret Nilai Nasionalisme dalam Kumpulan Cerpen Semua untuk Hindia Karya Iksaka Banu." Kode 9(4).

Foulcher, Keith. 2008. "Larut di Tempat yang Belum Terbentuk Mimikri dan Ambivalensi Dalam Sitti Noerbaja Marah Rusli." Dalam Sastra Indonesia Modern: Kritik Postkolonial. Jakarta: Yayasan Obor Indonesia.

Heryanto, Ariel. 2015. "Indonesia dalam Indo: Menghargai Semua untuk Hindia." Indoprogress.Com. $\quad$ Retrieved June 10,2021 (https://indoprogress.com/2015/04/indonesia-dalam-indo-menghargai-semua-untukhindia/).

Kamus Besar Bahasa Indonesia (KBBI) Daring. "Ideologi". Retrieved November 18, 2021 (https://kbbi.kemdikbud.go.id/entri/ideologi).

Khuzaini, A. H. 2018. "Kepribadian dan Aktualisasi Diri Tokoh Utama dalam Kumpulan Cerpen Semua untuk Hindia Karya Iksaka Banu (Kajian Psikologi Sastra)." EDUKATA 5(2):115-22.

Kuntowijoyo. 2006. Budaya dan Masyarakat. Yogyakarta: Tiara Wacana.

Loomba, Ania. 2016. Kolonialisme/Pascakolonialisme. Yogyakarta: Narasi.

Moleong, Lexy J. 2018. Metodologi Penelitian Kualitatif. Bandung: PT. Remaja Rosda Karya.

Raditya, Iswara N. 2018. "Untung Surapati, Bekas Budak yang Mengawini Perempuan Belanda." Tirto.Id. Retrieved June 12, 2021 (https://tirto.id/untung-surapati-bekasbudak-yang-mengawini-perempuan-belanda-cFj3).

Setiawan, Rahmat. 2018. Pascakolonial: Wacana, Teori, dan Aplikasi. Yogyakarta: Gambang Buku Budaya.

Stroomberg, J. 2018. Hindia Belanda 1930. Yogyakarta: IRCiSoD.

Suweleh, Fadlun. 2020. "Tokoh-tokoh Nativephilia dalam Antologi Cerpen Semua untuk Hindia Karya Iksaka Banu: Analisis Pascakolonial Homi K. Bhabha." Jentera 9(2):199-215.

Turama, Akhmad Rizqi. 2017. "Ambivalensi dalam Cerpen 'Anak Ini Mau Mengencingi Jakarta?' Karya Ahmad Tohari: Kajian Poskolonialisme.” Eufoni 1(1).

Wijaya, Guntur S., Achmad Zulfikar N., Alhadisatur Rofiqoh, Dwi Rofikoh, Widayawati, Khusnul Villah, Puji M. Arfi, and Syahrul Ramadhan W. 2019. "Peranan Untung Surapati di Wilayah Mataram dalam Babad Trunajaya-Surapati.” Suluk 1(1):51-58.

Young, Robert J. C. 2003. Postcolonialism: a Very Short Introduction. New York: Oxford University Press. 